\title{
Article
}

\section{Cellular Responses Induced by Zinc in Zebra Mussel Haemocytes. Loss of DNA Integrity as a Cellular Mechanism to Evaluate the Suitability of Nanocellulose-Based Materials in Nanoremediation}

\author{
Patrizia Guidi ${ }^{1}$, Margherita Bernardeschi ${ }^{1}{ }^{\circledR}$, Mara Palumbo ${ }^{1} \mathbb{C}$, Vittoria Scarcelli ${ }^{1}$, Massimo Genovese ${ }^{1} \mathbb{D}$, \\ Giuseppe Protano $^{2}{ }^{(}$, Valentina Vitiello ${ }^{3}$, Lorenzo Pontorno ${ }^{4}$, Lisa Bonciani ${ }^{4}$, Isabella Buttino ${ }^{3}{ }^{-0}$,

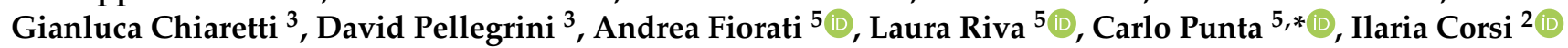 \\ and Giada Frenzilli ${ }^{1, *}$
}

Citation: Guidi, P.; Bernardeschi, M.; Palumbo, M.; Scarcelli, V.; Genovese, M.; Protano, G.; Vitiello, V.; Pontorno, L.; Bonciani, L.; Buttino, I.; et al. Cellular Responses Induced by Zinc in Zebra Mussel Haemocytes. Loss of DNA Integrity as a Cellular

Mechanism to Evaluate the Suitability of Nanocellulose-Based Materials in Nanoremediation. Nanomaterials 2021, 11, 2219. https://doi.org/10.3390/ nano11092219

Academic Editors: David M. Brown and Bing Yan

\section{Received: 9 July 2021}

Accepted: 26 August 2021

Published: 28 August 2021

Publisher's Note: MDPI stays neutral with regard to jurisdictional claims in published maps and institutional affiliations.

Copyright: (C) 2021 by the authors. Licensee MDPI, Basel, Switzerland. This article is an open access article distributed under the terms and conditions of the Creative Commons Attribution (CC BY) license (https:// creativecommons.org/licenses/by/ $4.0 /)$.
1 Department of Clinical and Experimental Medicine-Section of Applied Biology and Genetics and INSTM Local Unit, University of Pisa, 56126 Pisa, Italy; patrizia.guidi@unipi.it (P.G.); margherita.bernardeschi@for.unipi.it (M.B.); m.palumbo@studenti.unipi.it (M.P.); vittoria.scarcelli@unipi.it (V.S.); massimo.genovese@student.unisi.it (M.G.)

2 Department of Physical, Earth and Environmental Sciences and INSTM Local Unit, University of Siena, 53100 Siena, Italy; giuseppe.protano@unisi.it (G.P.); ilaria.corsi@unisi.it (I.C.)

3 Italian Institute for Environmental Protection and Research (ISPRA), Via del Cedro, 38, 57123 Livorno, Italy; valentina.vitiello@isprambiente.it (V.V.); isabella.buttino@isprambiente.it (I.B.); gianluca.chiaretti@isprambiente.it (G.C.); david.pellegrini@isprambiente.it (D.P.)

4 Biochemie Lab. S.r.l., Via di Limite 27G, 50013 Campi Bisenzio, Italy; 1.pontorno@biochemielab.it (L.P.); 1.bonciani@biochemielab.it (L.B.)

5 Department of Chemistry, Materials, and Chemical Engineering "G. Natta" and INSTM Local Unit, Politecnico di Milano, 20131 Milano, Italy; andrea.fiorati@polimi.it (A.F.); laura2.riva@polimi.it (L.R.)

* Correspondence: carlo.punta@polimi.it (C.P.); giada.frenzilli@unipi.it (G.F.); Tel.: +39-02-23993026 (C.P.); +39-050-2219111 (G.F.)

Abstract: Zinc environmental levels are increasing due to human activities, posing a threat to ecosystems and human health. Therefore, new tools able to remediate $\mathrm{Zn}$ contamination in freshwater are highly recommended. Specimens of Dreissena polymorpha (zebra mussel) were exposed for $48 \mathrm{~h}$ and 7 days to a wide range of $\mathrm{ZnCl}_{2}$ nominal concentrations (1-10-50-100 mg/L), including those environmentally relevant. Cellulose-based nanosponges (CNS) were also tested to assess their safety and suitability for $\mathrm{Zn}$ removal from freshwater. Zebra mussels were exposed to $50 \mathrm{mg} / \mathrm{L}$ $\mathrm{ZnCl}_{2}$ alone or incubated with $1.25 \mathrm{~g} / \mathrm{L}$ of $\mathrm{CNS}(2 \mathrm{~h})$ and then removed by filtration. The effect of Zn decontamination induced by CNS has been verified by the acute toxicity bioassay Microtox ${ }^{\circledR}$. DNA primary damage was investigated by the Comet assay; micronuclei frequency and nuclear morphological alterations were assessed by Cytome assay in mussels' haemocytes. The results confirmed the genotoxic effect of $\mathrm{ZnCl}_{2}$ in zebra mussel haemocytes at $48 \mathrm{~h}$ and 7-day exposure time. Zinc concentrations were measured in CNS, suggesting that cellulose-based nanosponges were able to remove $\mathrm{Zn}(\mathrm{II})$ by reducing its levels in exposure waters and soft tissues of $D$. polymorpha in agreement with the observed restoration of genetic damage exerted by zinc exposure alone.

Keywords: Dreissena polymorpha; freshwater nanoremediation; ecofriendly nanomaterials; polysaccharide-based materials; zinc bioaccumulation; acute toxicity; genotoxicity; DNA damage; micronucleus

\section{Introduction}

Among environmental contaminants, metals have gained attention because of their toxic and harmful effects on aquatic organisms and human health, also being able to induce genotoxicity through different mechanisms. Zinc $(\mathrm{Zn})$ is an essential element for 
life, the background level of which in river waters varies from less than 10 to $200 \mu \mathrm{g} / \mathrm{L}$ [1]. However, increasing $\mathrm{Zn}$ concentrations into the environment due to human activities (e.g., mining and industrial activity, agriculture, and traffic) represent a serious concern for ecosystems and human health. In terms of cellular toxicity, $\mathrm{Zn}$ has been reported to affect DNA by generating reactive oxygen species (ROS) or by directly binding to DNA and/or to impair the repair enzymes in marine bivalve [2].

Nano-based technology (nanotechnology) has dramatically increased over the last years and has influenced many areas of modern life, including cosmetics, pharmaceuticals, and medical devices [3]. Nanotechnology also makes use of nanomaterials for removing pollutants from environmental matrices (nanoremediation) [4]. Being more effective and less expensive than conventional in situ remediation techniques, nanoremediation is proposed as an environmentally and economically sustainable new technology $[5,6]$.

Nanomaterials employed in remediation processes, such as $\mathrm{TiO}_{2}$ nanoparticles (NPs), $\mathrm{ZnO} N \mathrm{Ns}$, and carbon nanotubes, have been reported to exert a certain degree of toxicity to the biota [7-12]; moreover, environmental fate of nanoparticles, after their release into contaminated areas, may cause potential risks and potential ecotoxicity [13].

Recently, sustainable cellulose-based nanomaterials are becoming increasingly attractive for their potential use in environmental remediation [14-19]. In this background, ecotoxicology can provide suitable tools able to select eco-safe and sustainable nanomaterials for environmental remediation [20].

In our previous works, we described the ability of a cellulose-based nanosponge (CNS) to efficiently remove organic pollutants (e.g., dyes, drugs, and other organic compounds) [21-23] and inorganic pollutants (e.g., Cd(II), $\mathrm{Cr}$ (III), $\mathrm{Cu}(\mathrm{II}), \mathrm{Hg}(\mathrm{II}), \mathrm{Ni}(\mathrm{II}), \mathrm{Co}(\mathrm{II})$, and $\mathrm{Zn}$ (II) ions) $[17,23]$ from contaminated water. In addition, we observed reduced genotoxicity caused by bivalent metals such as $\mathrm{Zn}$ in marine mussels (Mytilus galloprovincialis) [18] and Cd in zebra mussels (Dreissena polymorpha) [19]. Based on that, in the present study we aimed to test the ability of CNS to reduce zinc genotoxicity in zebra mussel haemocytes. The bivalve $D$. polymorpha was the model chosen to test the efficacy of zinc genotoxicity prevention as well as ecosafety of CNS based on its ability to remove heavy metals from freshwater. $\mathrm{Zn}$ (II) concentration in exposure waters and in soft tissues of zebra mussels were investigated before and after CNS treatment at time 0 and $48 \mathrm{~h}$ of exposure. $\mathrm{Zn}$ concentrations in CNS themselves before and after contact with $\mathrm{Zn}(50 \mathrm{mg} / \mathrm{L})$ were also measured, as well as acute toxicity. Genotoxic potential was evaluated at the molecular level by the Comet assay and at the chromosomal level by Cytome assay; acute toxicity was assessed by bioassay Microtox ${ }^{\circledR}$ using Aliivibrio fischeri.

\section{Materials and Methods}

\subsection{Reagents and Equipments}

$\mathrm{ZnCl}_{2}$ (CAS 7646-85-7), low and normal melting point agarose, Neutral Red, phosphate buffer saline were supplied by Sigma Aldrich (Milano, Italy), Giemsa by Carlo Erba (Milano, Italy). Cellulose from cotton linters was kindly provided by Bartoli SPA (Capannori, Lucca, Italy). Deionized water (DI) was prepared with a Millipore Elix ${ }^{\circledR}$ Deionizer equipped with a Progard ${ }^{\circledR}$ S2 ion exchange resins. The other equipment employed are: Branson Sonifier 250 (Branson Ultrasonic SA, Carouge, Switzerland), $6.5 \mathrm{~mm}$ probe tip and a SP Scientific BenchTop Pro Lyophilizer (Perugia, Italy) and a Transmission Electron Microscope (TEM; Philips CM 200, Koninklijke Philips N.V., Amsterdam, The Netherlands). Zeiss EVO 50 EP was provided by Carl Zeiss Microscopy Gmb (Jena, Germany). Milestone Ethos 900 microwave lab station (Sorisole, Italy). Lyophilised bacteria, all Microtox ${ }^{\circledR}$ reagents, Microtox ${ }^{\circledR}$ M500 luminometer and Microtox OMNI ${ }^{\mathrm{TM}}$ v. 1.16 software were obtained from ECOTOX LDS (Cornaredo, Milan, Italy). Coupled Plasma-Optical Emission Spectrometry (ICP-OES) was performed with Perkin Elmer Optica 8300 (Perkin Elmer, Waltham, MA, USA). Zn determination in soft tissues and CNS was carried out by inductively coupled plasma-mass spectrometry (ICP-MS) using the Perkin Elmer NexION 350 spectrometer (Waltham, MA, USA). 


\subsection{Preparation and Characterization of the Cellulose-Based Nanosponge (CNS)}

\subsubsection{Synthesis of TEMPO-Oxidized Cellulose}

Cellulose was oxidized as previously reported [24-26]. Briefly, cellulose (100 g) was dispersed in DI water (5.7 L) and 2,2,6,6-tetramethylpiperidine-1-oxyl (free radical) (TEMPO, $2.15 \mathrm{~g}, 13.8 \mathrm{mmol})$ and $\mathrm{KBr}(15.42 \mathrm{~g}, 129 \mathrm{mmol})$ were dissolved in the suspension. Then, an aqueous solution of $\mathrm{NaClO}(12.5 \% w / w, 437 \mathrm{~mL})$ was dropped to the slurry under vigorous stirring. During the reaction, the $\mathrm{pH}$ was kept in the range of $10.5-11$ by addition of $\mathrm{NaOH}_{\mathrm{aq}}(4 \mathrm{M})$. The reactive mixing was stirred overnight at room temperature. Then, $\mathrm{HCl}_{\mathrm{aq}}(12 \mathrm{M}, 5 \mathrm{~mL})$ was added in order to coagulate the oxidized cellulose, which finally was collected by filtration and intensively washed with DI $(6 \times 550 \mathrm{~mL})$.

The amount of carboxyl groups was evaluated by a colorimetric titration, exploiting phenolphthalein as colorimetric indicator. An oxidation degree of $1.5 \mathrm{mmol}_{\mathrm{COOH}} / \mathrm{g}_{\mathrm{TOCNF}}$ was measured.

\subsubsection{Synthesis of CNS}

CNS were prepared as previously reported $[17,21]$. In brief, $3.5 \mathrm{~g}$ of oxidized cellulose were suspended in DI $(2.5 \% w / v)$, and a stoichiometric amount of $\mathrm{NaOH}$ was added. The dispersion was ultrasonicated, in order to promote the separation of the TEMPO oxidized cellulose nanofibers (TOCNF), until the obtainment of a homogeneous and clear dispersion. The TOCNF dispersion was acidified with $\mathrm{HCl}_{\mathrm{aq}}(2 \mathrm{M})$, recovered by filtration and washed with DI until the percolated water reached $\mathrm{pH}$ 6-7. Then, $10 \mathrm{~mL}$ of an aqueous solution of bPEI $(2.5 \mathrm{KDa}, 0.35 \mathrm{~g} / \mathrm{mL})$ and $10 \mathrm{~mL}$ of aqueous citric acid (CA) solution $(0.0896 \mathrm{~g} / \mathrm{mL})$ were mixed with the TOCNF dispersion, under continuous stirring, obtaining a homogeneous hydrogel. This hydrogel was transferred in 24-plate multiwells, frozen at $-35^{\circ} \mathrm{C}$, and freeze-dried for $48 \mathrm{~h}$. The achieved xerogels were removed from the mold and thermally treated at $102{ }^{\circ} \mathrm{C}$ for $16 \mathrm{~h}$. The obtained CNS was ground in order to provide a fine powder and washed with DI water $(6 \times 40 \mathrm{~mL})$ and ethanol $(1 \times 40 \mathrm{~mL})$.

\subsubsection{Characterization of TOCNF and CNS}

The morphological characterization of TOCNF was obtained by a transmission electron microscope operating at $200 \mathrm{kV}$ and equipped with a field emission gun filament. Scanning electron microscopy (SEM) and SEM-EDS observations were carried out using a Zeiss EVO 50 EP scanning electron microscope (Zeiss International, Oberkochen, Germany) connected with a Bruker Quantax 200 6/30 detector (Bruker, Billerica, MA, USA) for Energy-dispersive X-ray spectroscopy (EDS) analysis (SEM Cambridge Stereoscan 360 ). The acceleration voltage was set to $20 \mathrm{kV}$ with an electron beam current intensity of $100 \mathrm{pA}$, operating at a working distance of $8.5 \mathrm{~mm}$. The specimens were used without any treatment.

\subsection{Sampling and Maintenance Condition}

Dreissena polymorpha specimens (medium valves length $2.01 \pm 0.5 \mathrm{~cm}$ ) were sampled from an artificial lake (Bilancino Lake, Tuscany, Italy), characterized by a $\mathrm{Zn}$ (II) concentration of $0.05 \pm 0.001 \mathrm{mg} / \mathrm{L}$. Mussels, in 3 independent samplings, were carried to the laboratory in lake original water and were placed 5 days before the dose-exposure experiment and 2 days before the co-exposition experiments in aquaria $(10 \mathrm{~L})$ containing aerated artificial freshwater (AFW) made of de-chlorinated tap (50\%) and distilled water (50\%) for the acclimatization period. A natural photoperiod was maintained and water temperature was $18 \pm 1{ }^{\circ} \mathrm{C}$, $\mathrm{pH}$ was $7.59 \pm 0.36$ for exposure experiments to zinc and $8.07 \pm 0.39$ for combined experiments where artificial freshwater contaminated by $\mathrm{Zn}$ (II) was combined with CNS. Independent experiments were carried out.

\subsection{In Vivo Exposure}

At the end of the acclimatization period, specimens of D. polymorpha were located on glass sheets placed in glass aerated tanks. The experimental design planned at least 
25 specimens for each group. Two different exposure times were included: $48 \mathrm{~h}$ for the Comet assay and 7 days for the Cytome assay. Animals fasted until being sacrificed, and only mussels re-attached by their byssus on glass sheets under the water were selected for the analysis [27]. Mussels were exposed to 1, 10, 50, and $100 \mathrm{mg} / \mathrm{L} \mathrm{Zn(II)} \mathrm{nominal} \mathrm{doses}$ for $48 \mathrm{~h}$ and 7 days of select sub-lethal concentration for the CNS efficacy combined study.

A stock solution was set up by dissolving $\mathrm{ZnCl}_{2}$ in distilled water. Final concentrations were prepared in AFW and chosen on the basis of these preliminary results and data from the literature [28], in order to work with environmentally realistic exposure levels. The threshold limit established by the Italian Minister for groundwater is actually $3 \mathrm{mg} / \mathrm{L}$, as well as the one for drinking water [29] and spring water [30], so lower and higher doses were selected. Moreover, combined experiment selected dose is representative of polluted water river, as in the Brazilian Toledo River, where the most impacted site was characterized by peaks of $50 \mathrm{mg} / \mathrm{L} \mathrm{Zn}$ water concentration [31]. The Zn(II) doses found to be genotoxic but not cytotoxic were 10 and $50 \mathrm{mg} / \mathrm{L}$. Thus, also taking into account environmentally relevant concentrations [31,32] $50 \mathrm{mg} / \mathrm{L}$ nominal dose was selected to test CNS.

The experiments aimed to assess CNS eco-safety and zinc adsorption efficacy in freshwaters were thus conducted (combined experiments). For this purpose, freshwater bivalves were exposed $(48 \mathrm{~h})$ to the following groups in AFW: $50 \mathrm{mg} / \mathrm{L} \mathrm{ZnCl}_{2}$ ( $\mathrm{Zn}(\mathrm{II})$ ), $50 \mathrm{mg} / \mathrm{L} \mathrm{ZnCl}{ }_{2}$ after treatment with CNS (Zn-t CNS), AFW after treatment with CNS alone (CNS). Controls were represented by specimens in solely artificial freshwater. Based on our previous study [18], the ratio of CNS able to adsorb Zn(II) from fresh waters was set up at $1.25 \mathrm{~g}$ of CNS in $1 \mathrm{~L}$ of artificial freshwater. A strong magnetic stirring $(2 \mathrm{~h}$ at room temperature) was exerted on the CNS samples in AFW to reproduce the protocol usually employed for polluted water. $0.45 \mu \mathrm{m}$ filters were used to remove CNS powder from the conditioned AFW and the bivalve specimens were exposed to the resulting water. The potential genotoxic effects of $\mathrm{Zn}$ (II) and CNS-treated AFW, alone and in combination, were assessed in D. polymorpha haemocytes. Cells were kindly aspirated from the posterior adductor muscle sinus and immediately employed for the Comet and Cytome assays [33]. Twenty-five specimens from each experimental group were used for biochemical analysis.

\subsection{Zinc Concentration in Water}

Chemical analyses were performed on water samples collected from each aquarium immediately after the treatment and at the end of the exposure time $(48 \mathrm{~h})$ and then stored at $4{ }^{\circ} \mathrm{C}$. Zinc concentrations were measured through an Inductively Coupled Plasma-Optical Emission Spectrometry (ICP-OES) using a Perkin Elmer Optica 8300 (PerkinElmer, Inc., Waltham, MA, USA), equipped with a CrossFlow nebulizer and a Scott Spray Chamber, followed by a standard quartz torch. The instrument calibration was performed by dilution of a zinc analytical standard (FLUKA), with MilliQ ${ }^{\circledR}$ water (Merk Life Science, Milano, Italy) obtaining 5, 10, and $50 \mu \mathrm{g} / \mathrm{L}$ solutions; to each analyzed samples, Y (2 mg/L) was added as internal standard.

\subsection{Zn Concentrations in CNS and Zebra Mussel}

Zinc concentrations were measured in CNS $(1.25 \mathrm{~g} / \mathrm{L})$ after $2 \mathrm{~h}$ of incubation in AFW and in AFW with $50 \mathrm{mg} / \mathrm{L} \mathrm{Zn(II),} \mathrm{and} \mathrm{in} \mathrm{whole} \mathrm{soft} \mathrm{tissues} \mathrm{of} \mathrm{D.} \mathrm{polymorpha} \mathrm{at} \mathrm{the} \mathrm{end} \mathrm{of}$ the exposure time $(48 \mathrm{~h}$ ) in all the tanks: control (AFW), AFW treated with CNS only (CNS), $50 \mathrm{mg} / \mathrm{L} \mathrm{Zn(II)} \mathrm{in} \mathrm{AFW} \mathrm{treated} \mathrm{with} \mathrm{CNS} \mathrm{(Zn-t} \mathrm{CNS),} 50 \mathrm{mg} / \mathrm{L} \mathrm{ZnCl} 2$ in AFW (Zn(II)).

CNS were collected from the filters used to remove them from exposure waters and dried at $+30{ }^{\circ} \mathrm{C}$ in a ventilated oven. Ten individuals of zebra mussel from each experimental group were freeze-dried after removing the valves using a Labogene, Scanvac (Labogene, Nyköping, Sweeden) cool safe ( 0.5 torr pressure, $\left.\mathrm{T}=-50^{\circ} \mathrm{C}\right)$.

CNS and zebra mussels' whole soft tissues were solubilized by means of microwaveassisted acid digestion by adding $3 \mathrm{~mL} \mathrm{HNO}_{3}$ and $0.5 \mathrm{~mL} \mathrm{H}_{2} \mathrm{O}_{2}$ (ultrapure reagents) to 
about $250 \mathrm{mg}$ of sample. Solubilization was carried out in Teflon bombs in a Milestone Ethos 900 microwave lab station (Milestone, Sorisole, Italy).

Determination of $\mathrm{Zn}$ concentrations in CNS and zebra mussel was performed by inductively coupled plasma-mass spectrometry (ICP-MS). To assess analytical accuracy, the following standard reference materials with certified $\mathrm{Zn}$ concentrations were analyzed: GBW 07604 (Poplar Leaves) of Institute of Geophysical and Geochemical Exploration (Langfang, China) and SRM 2977 (Mussel Tissue) of National Institute of Standards and Technology (Gaithersburg, MD, USA). Zn recoveries were 99.1 and $100.3 \%$ for GBW 07604, 99.3, and 99.6\% for SRM 2977. The precision of Zn measurements was defined through the percentage relative standard deviation (\% RSD) of five replicate analyses of $\mathrm{Zn}$ (II) in each CNS and zebra mussel sample. The values of $\%$ RSD were below $0.7 \%$.

\subsection{Viability Assessment}

The Neutral Red Retention Time (NRRT) assay was used as a measure of cytotoxicity due to its recommended use for regulatory cytotoxicity evaluation of chemicals by OECD and NIH, USA [34] and widely used to assess cell viability. It is used to distinguish cells actively retaining the neutral red dye inside their lysosomal membranes from cells unable to do it. Neutral Red Retention Time assay was performed according to Guidi and collaborators [33]. The Comet assay was applied only on haemocytes that displayed a cell toxicity $<10 \%$ in order to exclude potential false positive data.

\subsection{Comet Assay}

The Comet assay was carried out on haemocytes from 10 zebra mussels taken from each experimental group at the end of the exposure time, according to Guidi et al. [35]. During haemolymph collection, individual cell suspensions were stored at $+4{ }^{\circ} \mathrm{C}$ in the dark and then samples were centrifuged for $10 \mathrm{~min}$ at $125 \times \mathrm{g}$. Cell pellet was embedded in $75 \mu \mathrm{L}$ of freshly made $0.5 \%$ LMA and spread on microscopy glass slides, pre-coated with a layer of $1 \%$ NMA. The second layer agarose polymerization was allowed for $5 \mathrm{~min}$ on metal trays at $+4{ }^{\circ} \mathrm{C}$, and then an additional layer of $85 \mu \mathrm{L}$ of $0.5 \%$ LMA was added. Following agarose solidification at $+4{ }^{\circ} \mathrm{C}$, slides were immersed in freshly made lysing solution $(10 \mathrm{mM}$ Tris, $2.5 \mathrm{M} \mathrm{NaCl}, 1 \%$ Triton X 100, $0.1 \mathrm{M}$ EDTA and 10\% DMSO, pH 10) for at least $1 \mathrm{~h}$. To allow DNA unwinding in alkaline conditions, a horizontal gel electrophoresis chamber was used to incubate slides for $10 \mathrm{~min}$ at $+4^{\circ} \mathrm{C}$ with fresh electrophoresis buffer $(0.075 \mathrm{M} \mathrm{NaOH}$, $1 \mathrm{mM}$ EDTA, $\mathrm{pH} \geq 13$ ). Electrophoresis was performed at $25 \mathrm{~V}, 300 \mathrm{~mA}$, for $5 \mathrm{~min}$ at $+4^{\circ} \mathrm{C}$. To neutralize the $\mathrm{pH}$, and allow DNA staining, at the end of the electrophoresis run, slides were washed three times ( 5 min each) with a neutralization solution (Tris- $\mathrm{HCl}, \mathrm{pH} 7.5$ ). Slides were stained with ethidium bromide and scored under a fluorescence microscope $(400 \times)$. An image analyzer (Kinetic imaging, Ltd., Liverpool, United Kingdom, Komet, Version 5) was used and the parameter chosen to quantify the amount of DNA damage was the percentage of DNA migrated into the comet tail (\% tail DNA) [36]. At least 50 randomly chosen nuclei per slide and 2 slides per sample were scored, for a total of 100 nuclei per organisms and the mean calculated.

\subsection{Cytome Assay}

Chromosomal damage was evaluated by assessing the frequency of micronucleated haemocytes and nuclear abnormalities. The cytome assay was performed according to Guidi et al. [33]. For chromosomal damage evaluation, 500 well-preserved cytoplasm haemocytes per specimen were analyzed at light microscope, as suggested by Fenech (2007) [37]. These nuclear morphology alterations (NA) were included: nuclear blebs (BL), nuclear buds (NBUD), notched nucleus (NT), circular nucleus (CIR), lobed nucleus (LB), nucleoplasmic bridges (NPB), anisochromatic nuclei (AN), and apoptotic cells (APO). NPB are the expression of the chromosomal mutation "dicentric chromosome" coming from the joint of two broken chromosomes. For each experimental group 10 animals, 2 slides per animal, 500 cells per slide were observed. 


\subsection{Acute Toxicity Test with Aliivibrio Fischeri}

Water samples were taken from the controls (AFW), CNS and Zn-t CNS treatments immediately (t0) and at the end of the exposure time (48) $\mathrm{h}$, and stored at $-20{ }^{\circ} \mathrm{C}$ until the analysis. Previously, an acute test with Aliivibrio fischeri exposed to the nominal dose of $50 \mathrm{mg} / \mathrm{L} \mathrm{Zn(II)} \mathrm{solution} \mathrm{was} \mathrm{performed} \mathrm{to} \mathrm{evaluate} \mathrm{EC50.} \mathrm{After} \mathrm{reactivation,} \mathrm{bacteria} \mathrm{were}$ added in each samples dilutions and incubated at $15^{\circ} \mathrm{C}$ using Microtox M500 luminometer. Bacteria light emission was recorded for each dilution and replicated at the beginning of incubation and after 5, 15, and $30 \mathrm{~min}$ of exposure.

Data were analyzed using the MicrotoxOmni ${ }^{\mathrm{TM}}$ software (version, 4.2, Modern Water, London, UK), which calculated Maximum Effect percentage for each exposure time and effect concentrations EC20 and EC50 when low luminescence values are recorded by the luminometer. The acute toxicity test was determined following the Basic $90 \%$ Protocol ISO 11348 [38], with seven sample dilutions and three replicate of controls. Toxicity was calculated by using maximum effect percentages or EC20 and EC50 values, in accord with ICRAM-APAT 2007 [39].

\subsection{Statistical Analysis}

Data from at least 5 animals were analyzed by a statistical software Statgraphics Centurion XV (version 15.1.02, by StatPoint, Inc., Warrenton, VA, USA) from each experimental point. Being an in vivo study, each animal was considered as a statistical unit, then mean $\pm \mathrm{SD}$ was considered per experimental group. Results are represented as mean $\pm \mathrm{SD}$ after multifactor analysis of variance (MANOVA). In order to investigate differences among the experimental groups, the multiple range test (MRT) was applied. For all the analyses, a statistical significance level of $p<0.05$ was set up [40].

\section{Results and Discussion}

The main purpose of this study was to investigate the safeness and efficacy of CNS obtained by renewable sources in preventing zinc-induced genotoxicity in zebra mussel haemocytes.

\subsection{Dose-Effect Experiments}

In order to select a genotoxic and sub-cytotoxic dose evaluated by the Comet assay to be used for the co-exposure investigations with CNS, zebra mussels were exposed to different concentrations of $\mathrm{Zn}(\mathrm{II})$. A loss of DNA integrity was detectable $(p<0.05)$ at the nominal doses of 1, 10, 50, and $100 \mathrm{mg} / \mathrm{L} \mathrm{Zn(II)} \mathrm{after} 48 \mathrm{~h}$ exposure (Figure 1). Cytotoxicity was observed at the nominal dose of $100 \mathrm{mg} / \mathrm{L}$ (data not shown). However, we verified that starting from the $50 \mathrm{mg} / \mathrm{L} \mathrm{Zn(II)} \mathrm{solution} \mathrm{in} \mathrm{AFW,} \mathrm{a} \mathrm{white} \mathrm{precipitate} \mathrm{occurred} \mathrm{after} \mathrm{a}$ few minutes. We assumed this behavior could be ascribed to the presence of carbonates in AFW, containing 50\% of de-chlorinated tap, which would lead to the formation of low soluble zinc carbonates. As a matter of fact, $\mathrm{Zn}$ (II) concentration in this case suddenly decreased in a range between $20-30 \mathrm{mg} / \mathrm{L}$ for the nominal dose of $50 \mathrm{mg} / \mathrm{L}$ and in a range between $35.5-47.6 \mathrm{mg} / \mathrm{L}$ for the nominal dose of $100 \mathrm{mg} / \mathrm{L}$. Nevertheless, even in this range, genotoxic action of $\mathrm{Zn}(\mathrm{II})$ was observed, as reported in Figure 1. Although the background level of DNA damage in control zebra mussels obtained in the present study does not overlap with recommended values suggested by Tice and co-authors [41], data from literature reported high background levels obtained by the Comet assay in $D$. polymorpha and in other aquatic organisms [19,42]. Baseline levels of DNA damage in zebra mussel haemocytes were also found to correlate with animal maintenance temperature [43]. We also cannot ignore that results obtained from AFW experimental group might have been modulated by other factors such as water quality of sample site and/or origin population genetic background. It is important to underline that the results obtained from the control tank were able to discriminate the exposure effects indicating a DNA integrity degree acceptable for a control sample. 


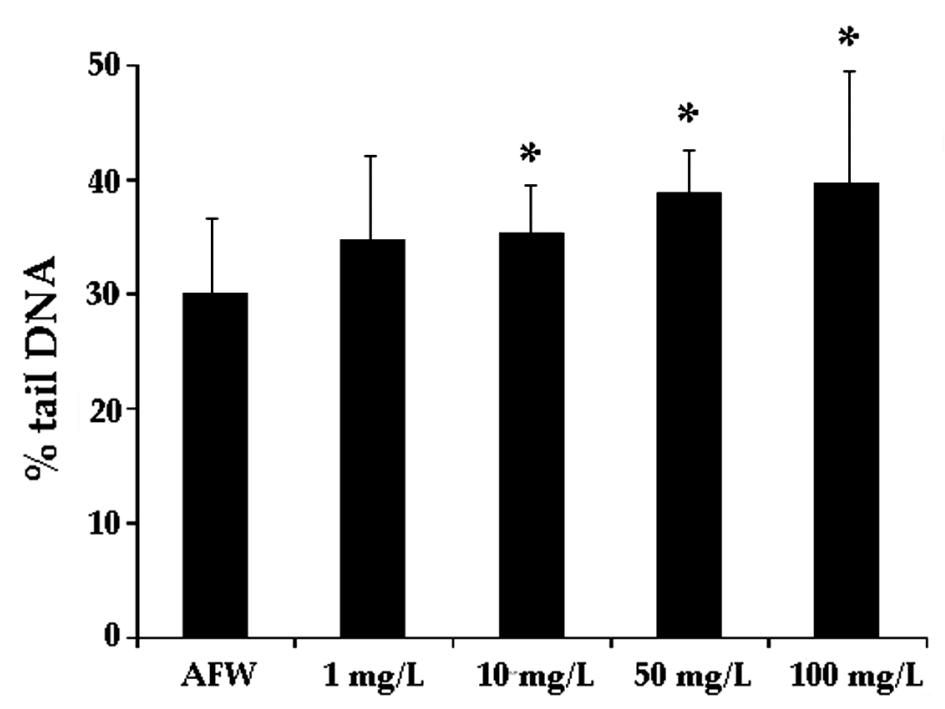

Figure 1. DNA primary damage (\% tail DNA) in zebra mussels' haemocytes after $48 \mathrm{~h}$ of exposure to the following experimental groups: AFW (control); 1-10-50-100 mg/L Zn(II)nominal doses in AFW. Data are shown as mean \pm SD. $\left(^{*}\right)$ indicates significant difference respect to the control group (AFW) $(p<0.05)$.

The sensitivity of zebra mussels to genotoxic agents has been demonstrated through the induction of micronuclei and DNA strand-breaks [44,45]. Similarly, field studies revealed an increase of DNA damage in haemocytes of zebra mussels inhabiting polluted sites, which correlated with the level of contaminants in water [27]. In the present study in vivo zinc exposure induced a statistically significant increase of DNA strand breaks compared to controls, confirming data from the literature evaluated in different sentinel species [46-48], being Zn induced DNA damage also known to occur in marine mussels' cells $[18,49,50]$.

In terms of chromosomal damage and nuclear abnormalities, an induction of micronucleated cells $(p<0.05)$ and nucleoplasmic bridges $(p<0.05)$ were assessed after the exposure to highest dose of $\mathrm{Zn}(\mathrm{II})$. Apoptotic nuclei were observed in the absence of necrotic events. Treatment groups were not statistically different from the control in terms of apoptosis (Table 1).

Table 1. Frequency (\%o) of Micronucleated cells (MN), Nucleoplasmic Bridges (NPB), apoptotic cells, and necrotic cells in zebra mussel haemocytes after exposure to different nominal doses of $\mathrm{Zn}(\mathrm{II}): 1 \mathrm{mg} / \mathrm{L} /, 10 \mathrm{mg} / \mathrm{L}, 50 \mathrm{mg} / \mathrm{L}, 100 \mathrm{mg} / \mathrm{L} .\left(^{*}\right)$ indicates significant differences respect to the control group.

\begin{tabular}{cccccc}
\hline & $\mathbf{C}$ & $\mathbf{1} \mathbf{~} \mathbf{g} / \mathbf{L}$ & $\mathbf{1 0 ~} \mathbf{~ g} / \mathbf{L}$ & $\mathbf{5 0 ~} \mathbf{~ g} / \mathbf{L}$ & $\mathbf{1 0 0} \mathbf{~} \mathbf{g} / \mathbf{L}$ \\
\hline MN & $0.95 \pm 1.50$ & $1.65 \pm 2.06$ & $1.10 \pm 1.17$ & $1.50 \pm 1.29$ & $1.95 \pm 1.93^{*}$ \\
NPB & $1.05 \pm 1.96$ & $2.50 \pm 2.80$ & $2.90 \pm 4.09$ & $3.00 \pm 3.01$ & $3.70 \pm 4.57^{*}$ \\
Apoptosis & $7.60 \pm 10.88$ & $8.90 \pm 9.53$ & $5.10 \pm 3.70$ & $13.44 \pm 22.49$ & $15.10 \pm 14.29$ \\
Necrosis & $0.00 \pm 0.00$ & $0.05 \pm 0.22$ & $0.00 \pm 0.00$ & $0.00 \pm 0.00$ & $0.00 \pm 0.00$ \\
\hline
\end{tabular}

Zinc is also known to induce chromosomal damage in aquatic species [51]. In gill cells, Majone et al. [52] found that mussels exposed under controlled laboratory conditions to $\mathrm{ZnCl}_{2}$ showed a clear increase in $\mathrm{MN}$ frequencies after treatment, suggesting that this metal even at low concentration $(0.17 \mathrm{mg} / \mathrm{L})$ and in short term exposure $(48 \mathrm{~h})$ exerts a clear clastogenic activity. The presence of nucleoplasmic bridges coming from two clastogenic events seems to confirm this mechanism of action possessed by zinc. As reported in the literature, nuclear abnormalities have been used as a marker of genotoxicity in marine mussels' cells [53], even related with heavy metal exposure [54]. In literature, the majority 
of data regarding apoptotic cell frequency in zebra mussel was obtained through the diffusion (or halo) assay. Values ranged between 2 and 4 apoptotic nuclei per 100 cells scored, which means they represent about the $2 \%$ of the cell population analyzed $[55,56]$. These values are similar to those reported here, even if they originated from Cytome assay slides analysis, since the relationship between the apoptotic nuclei scored and the total amount of cells scored is quite the same (7-14/1000 cells).

\subsection{Combined Experiments}

3.2.1. Synthesis and Characterization of Cellulose Nanosponges

TEM analysis of TOCNF confirmed the expected morphology of the fibers [25], characterized by a micrometric length and nanometric width (Figure 2A). These nanofibers were used as building blocks for the production of cellulose-based nanosponges (CNS), which were synthesized according to Figure 3, following a multistep procedure previously optimized [17]. The formulation required a 1:1 weight ratio between TOCNF and bPEI and the addition of $18 \%$ of CA with respect to primary amino groups of bPEI. CA is needed to increase the bPEI crosslink within the final network.

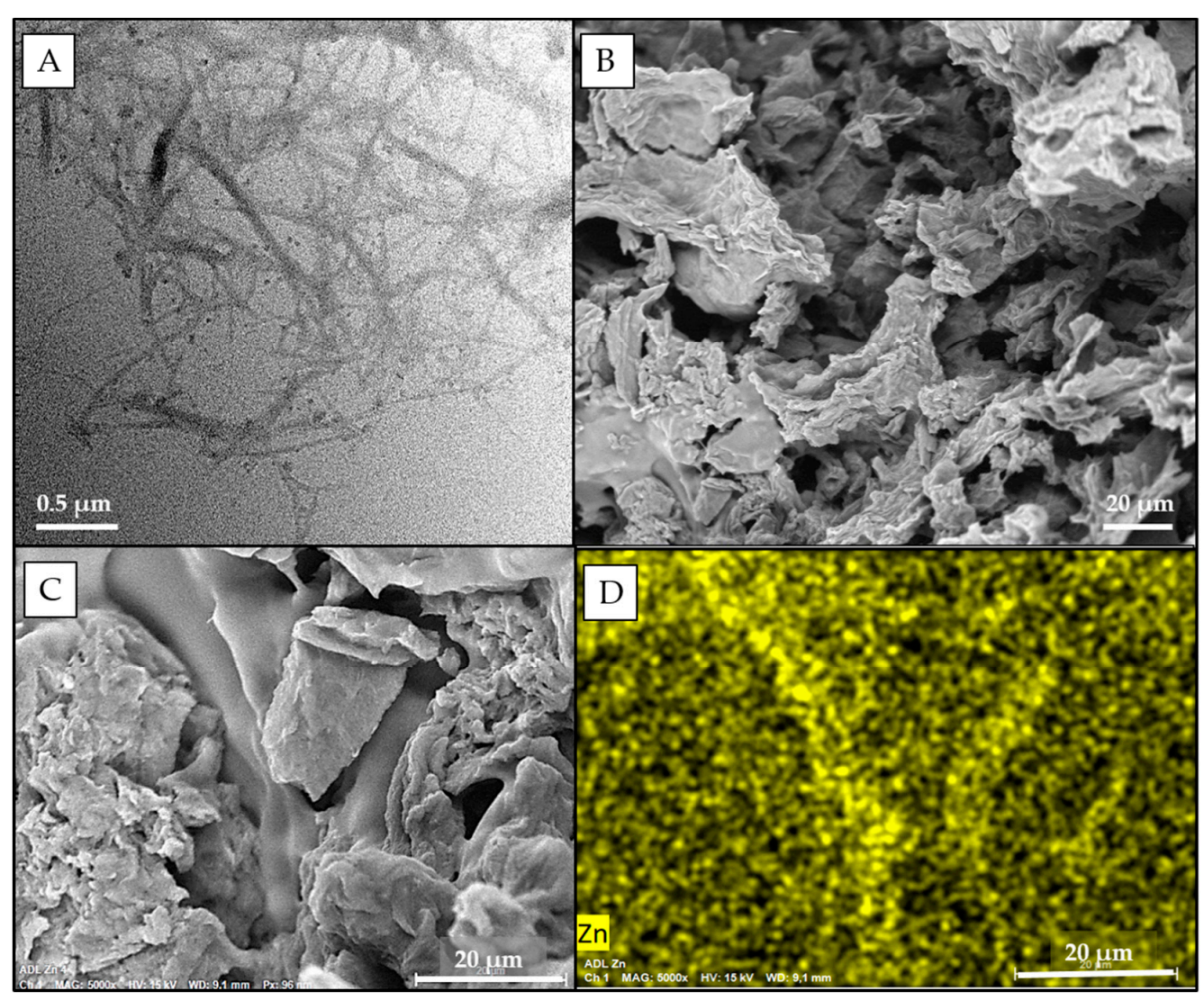

Figure 2. (A) TEM image of TOCNF; (B) SEM image of CNS powder before zinc decontamination activity; (C) SEM image of CNS powder after Zn adsorption; (D) SEM-EDS image of CNS after Zn adsorption clearly showing the presence of $\mathrm{Zn}$ on the nanosponge (yellow dots). 


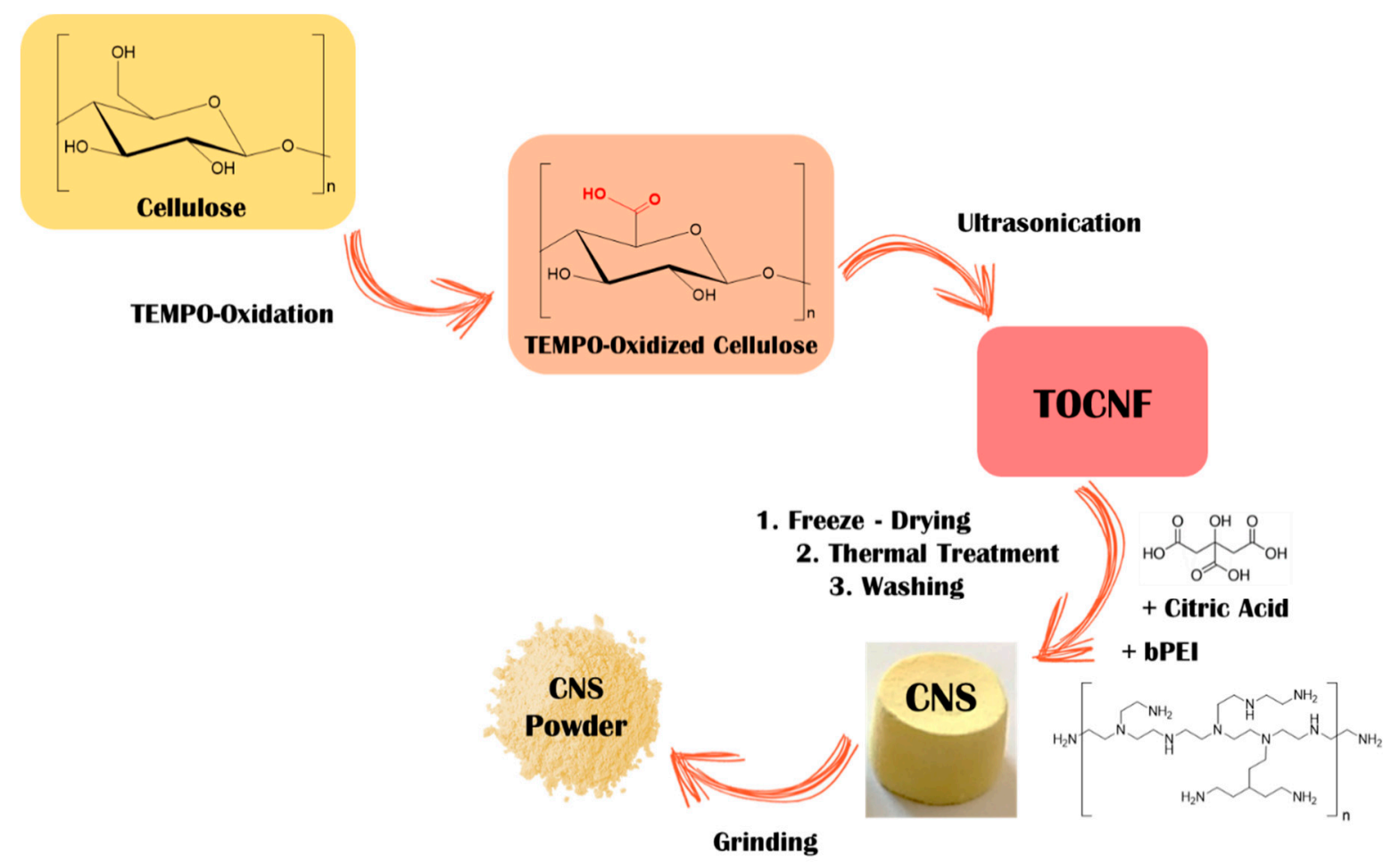

Figure 3. Synthesis of cellulose-based nanosponges (CNS).

A detailed and fully comprehensive characterization of CNS was reported in previous works. In particular, the FT-IR analysis evidenced the presence of the $-\mathrm{C}=\mathrm{O}$ stretching vibrational mode of the amide functional groups (peak at $1664 \mathrm{~cm}^{-1}$ ), while the ${ }^{13} \mathrm{C} \mathrm{CP}$ MAS solid-state NMR and the elemental analysis also confirmed the role of CA in better fixing bPEI in the network [22,57,58].

An SEM image of CNS reported in Figure 2B confirms the expected high microporosity of the system, due to the pristine formation water ice crystals, with a twodimensional sheet-like morphology and a pore size in the range of 10-100 micrometers. Moreover, the microcomputed tomography $(\mu-\mathrm{CT})$ analysis reported in Fiorati et al. [22] indicated that CNS possesses a trabecular inner structure, which has an average trabecular thickness of about 30-40 $\mu \mathrm{m}$, a trabecular separation of about $70-75 \mu \mathrm{m}$, and a porosity of $70-75 \%$.

Besides the evident micro-porosity of the network, a recent analysis of water nanoconfinement geometries in CNS, conducted by small angle neutron scattering (SANS) technique, provided the first experimental evidence of nano-dimensioned porosity in the sorbent material, allowing a measurement of short-range correlation length in the range between 25 and $35 \AA$ [57]. Moreover, an in-depth FTIR-ATR investigation of CNS hydrated with $\mathrm{H}_{2} \mathrm{O}$ and $\mathrm{D}_{2} \mathrm{O}$ allowed supporting the findings of a nano-confinement of water by detecting a supercooled behavior on the entrapped water molecules [58].

\subsubsection{Zn(II) Adsorption Efficiency of CNS}

Results of the ICP-OES analysis on all the experimental points are reported in Table 2. In control (AFW) and AFW treated with CNS (CNS), the Zn(II) concentration was found to be insignificant. Different from what is observed above, $\mathrm{Zn}$ (II)-contaminated AFW $(50 \mathrm{mg} / \mathrm{L})$ treated with $1.25 \mathrm{~g} / \mathrm{L} \mathrm{CNS}$ (Zn-t CNS) showed a significant decrease in Zn concentration (up to $94 \%$ ) in comparison with Zn(II) contaminated AFW (Zn-t AFW). It is to note that in the $\mathrm{Zn}$-t CNS experimental group, the level of $\mathrm{Zn}$ (II) in zinc-contaminated water decreased to the values authorized by Italian law $(3 \mathrm{mg} / \mathrm{L})$ for drinking water. 
Table 2. $\mathrm{Zn}(\mathrm{II})$ concentration $(\mathrm{mg} / \mathrm{L})$ in zebra mussels' exposure waters at time zero $\left(\mathrm{T}_{0}\right)$ (soon after preparation and expoScheme $48 \mathrm{~h}$ ( $\mathrm{T}_{48}$ ) for AFW (control); Zn(II) $50 \mathrm{mg} / \mathrm{L}$ in AFW; Zn-t CNS (Zn(II) $50 \mathrm{mg} / \mathrm{L}$ contaminated AFW treated with CNS), CNS (AFW treated with CNS only). Data are reported as mean $\pm \mathrm{SD}$ from three independent experiments. $\left(^{*}\right) p<0.05$ respect to control within the same exposure time (\#) $p<0.05$ comparison between the two exposure times.

\begin{tabular}{ccc}
\hline Exposure Group & Zn(II) $\mathbf{T}_{\mathbf{0}}[\mathbf{m g} / \mathbf{L}]$ & Zn(II) $\mathbf{T}_{\mathbf{4 8}}[\mathrm{mg} / \mathrm{L}]$ \\
\hline AFW & $0.022 \pm 0.003$ & $0.02 \pm 0.014$ \\
Zn(II) & $28.15 \pm 6.84^{*}$ & $5.17 \pm 3.60^{*}$ \\
CNS & $0.183 \pm 0.11$ & $0.145 \pm 0.12$ \\
Zn-t CNS & $1.92 \pm 0.39 \#$ & $0.45 \pm 0.035$ \\
\hline
\end{tabular}

Looking at $\mathrm{Zn}$ levels in nanosponges recovered after $2 \mathrm{~h}$ in AFW alone (AFW) and AFW contaminated by Zn (Zn-t CNS), the adsorption efficacy of CNS towards Zn was confirmed. In fact, $\mathrm{Zn}$ concentration of $365.23 \pm 177 \mu \mathrm{g} / \mathrm{g}$ was measured in CNS from $\mathrm{Zn}$-contaminated AFW, whereas $\mathrm{Zn}$ (II) level of $16.04 \pm 0.11$ was found in CNS alone in AFW. Moreover, SEM-EDS images of CNS powder from Zn-t CNS clearly proved the immobilization of $\mathrm{Zn}$ ions on the CNS (Figure 2D).

Interestingly, $\mathrm{Zn}$ concentration in the $\mathrm{Zn}$ (II) experimental group at $\mathrm{T}_{0}$ was found to be much lower than expected ( $28 \mathrm{mg} / \mathrm{L}$ against the expected $50 \mathrm{mg} / \mathrm{L})$. Moreover, after $48 \mathrm{~h}$ of exposure Zn(II), concentration in Zn-contaminated AFW further decreased, in respect to the sample analyzed soon after preparation $\left(T_{0}\right)$, suggesting a possible role of zebra mussels in filtering and accumulating the $\mathrm{Zn}$ ions.

For this reason, the amounts of $\mathrm{Zn}(\mathrm{II})$ in the whole soft tissue of zebra mussels were determined in all exposure groups. Indeed, level of $\mathrm{Zn}$ (II) in mussels exposed to Zn-t CNS $(171.66 \pm 0.44 \mu \mathrm{g} / \mathrm{g}$ d.w.) was significantly lower, compared to that in individuals exposed to only $\mathrm{Zn}$ (II) (505.5 $\pm 3.28 \mu \mathrm{g} / \mathrm{g}$ d.w.; Table 3).

Table 3. Zn concentration ( $\mu \mathrm{g} / \mathrm{g}$ dry weight) in zebra mussels' whole soft tissue after $48 \mathrm{~h}\left(\mathrm{~T}_{48}\right)$ of exposure as follows: AFW (control); Zn(II) $50 \mathrm{mg} / \mathrm{L}$ in AFW; Zn-t CNS (Zn(II) $50 \mathrm{mg} / \mathrm{L}$ contaminated AFW treated with CNS, CNS (AFW treated with CNS only). Data are reported as mean \pm SD. ${ }^{*} p<0.05 ;{ }^{* *} p<0.01$ in respect to the controls (ASW).

\begin{tabular}{cc}
\hline Exposure Group & Zn(II) $\mathrm{T}_{48}[\mu \mathrm{g} / \mathrm{g}]$ \\
\hline AFW & $121.36 \pm 0.54$ \\
Zn (II) & $505.50 \pm 3.28^{* *}$ \\
CNS & $126.05 \pm 0.44$ \\
Zn-t CNS & $171.66 \pm 0.44^{*}$ \\
\hline
\end{tabular}

$\mathrm{Zn}$ (II) level in zebra mussels exposed to CNS alone (CNS) was similar to the control (AFW): 126.05 ( \pm 0.44$)$ vs. 121.36 ( \pm 0.54$) \mu \mathrm{g} / \mathrm{g}$ d.w. As further proof, $\mathrm{Zn}(\mathrm{II})$ body burden in zebra mussels collected from the Bilancino Lake before the acclimatation was 104.91 $( \pm 0.36) \mu \mathrm{g} / \mathrm{g}$ d.w. If, from one side, this result confirms again the effective role of CNS in removing $\mathrm{Zn}(\mathrm{II})$ from the AFW medium, the $\mathrm{Zn}(\mathrm{II})$ amounts found in mussels exposed to $\mathrm{Zn}(\mathrm{Zn}(\mathrm{II}))$ did not justify the significant decrease in metal water concentration at $\mathrm{T}_{48}$. For this reason, we assumed that upon uptake by zebra mussel, $\mathrm{Zn}(\mathrm{II})$ is partially released in feces, as confirmed by SEM images thus explaining the low levels found in exposure waters (Figure 4). 

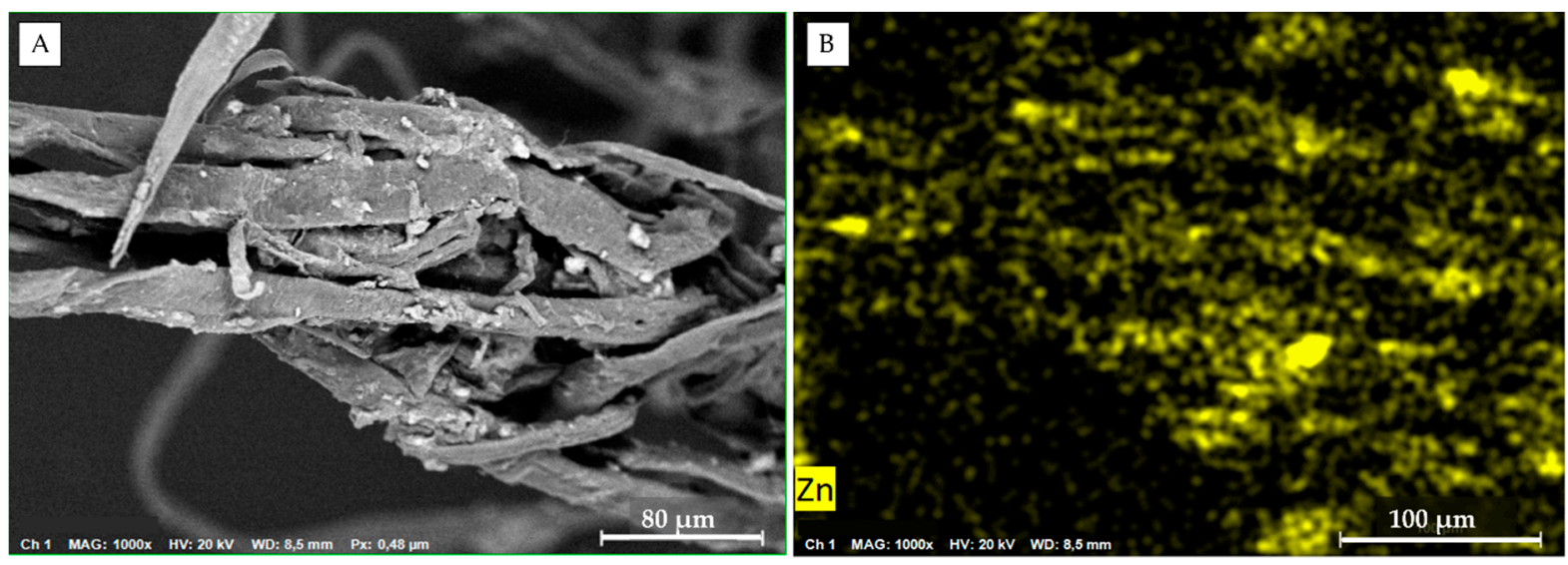

Figure 4. SEM images in D. polymorpha' feces: (A) SEM image with evidence of aggregates on the fibers; (B) SEM-EDS image of faces clearly showing the presence of $\mathrm{Zn}$ (yellow dots).

Although the exposure period was only $48 \mathrm{~h}$, it might be suggested that $D$. polymorpha is capable of regulating the body concentration of essential metals such as $\mathrm{Zn}$ [59]. More than half of the accumulated $\mathrm{Zn}$ was reported to be found in feces after $24 \mathrm{~h}$ [60] in D. polymorpha. Moreover, regulation is considered as an active process in the decapod Palaemon elegans, where an increased rate of $\mathrm{Zn}$ uptake was matched by an increase of $\mathrm{Zn}$ excretion [61], indicating the important role of bio-deposition, besides bioaccumulation.

\subsubsection{Genotoxicity}

For the second set of experiments, the water samples were pretreated with CNS alone (CNS) or in combination with Zn(II) (Zn-t CNS) and the nominal dose of $50 \mathrm{mg} / \mathrm{L}$ (Zn50) was selected as genotoxic but not cytotoxic. Specimens exposed to AFW treated with CNS did not affect haemocytes' DNA integrity. On the contrary, Zn50 induced a statistically significant increase in DNA primary damage, compared to the controls $(p<0.05)$. $\mathrm{ZnCl}_{2}$ in synthetic water previously flown through polysaccharide-based adsorbent CNS did not show any loss of DNA integrity in comparison with the control group, thus suggesting that polysaccharide-based nanosponges are able to soften $\mathrm{ZnCl}_{2}$ induced-DNA primary damage in zebra mussel haemocytes (Figure 5).

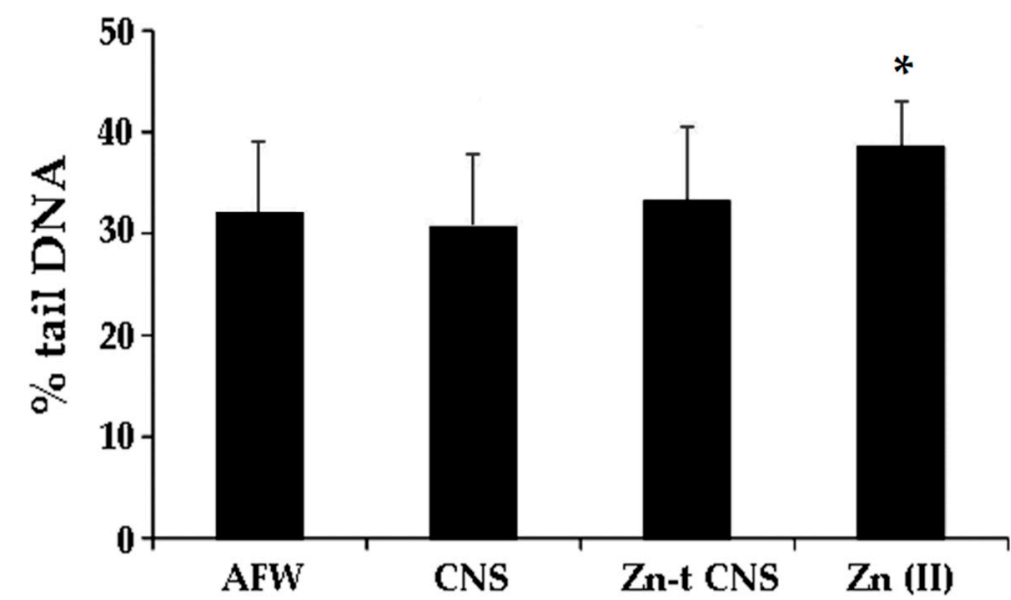

Figure 5. DNA primary damage (\% tail DNA) in zebra mussels' haemocytes after $48 \mathrm{~h}$ of exposure to the following experimental groups: AFW (control); $\mathrm{Zn}$ (II) $\left(\mathrm{ZnCl}_{2} 50 \mathrm{mg} / \mathrm{L}\right.$ in AFW); $\mathrm{Zn}$-t CNS (Zn(II) $50 \mathrm{mg} / \mathrm{L}$ ) contaminated AFW treated with CNS), CNS (AFW treated with CNS only). Data are reported as mean $\pm \mathrm{SD} .{ }^{*}$ indicates statistically $(p<0.05)$ significant differences respect to the control. 
A relatively weak positive correlation was found between DNA primary damage and water $\mathrm{Zn}$ (II) concentration ( $p=0.02$; c.c. $=-0.30 ; \mathrm{r}^{2}=9.3$ ) while there is no statistically significant relationship between the frequency of micronucleated cells and $\mathrm{Zn}$ (II) concentration in exposure waters. There is a lack of investigation regarding correlations between DNA damage in aquatic specimens and water zinc concentration. In a polluted Brazilian river, Matos and co-workers (2017) [32] found higher genotoxic effects in fish sampled at the Zn most contaminated sites, but Zn levels were not directly correlated to toxicogenetic damage. On the contrary, Sargsyan and colleagues [62] found a positive correlation between DNA damage in D. armeniaca and content in the soil of $\mathrm{Zn}$. Even if we are aware that researchers investigated a terrestrial animal, and the metal concentrations were detected in the soil, these data seem to support our observation. In terms of micronucleated cells frequency no statistically significant results were obtained after seven-day exposure (data not shown). Specimens exposed to AFW treated with CNS did not show any increase in micronucleated haemocytes. Similarly, no induction of nucleoplasmic bridges was found after the exposure to CNS in AFW only. With the present experimental approach, we were able to appreciate the suitability of CNS as Zn(II) removal in freshwater, which, besides the absence of adverse genotoxic effects, is able to prevent zinc-induced DNA integrity loss in D. polymorpha hemocytes, in agreement with previous findings on the marine bivalve M. galloprovincialis [18]. CNS themselves did not induce any DNA integrity loss, also at the chromosomal level. In fact, no statistically significant increase of in cells or nucleoplasmatic bridges were detected in specimens exposed to $1.25 \mathrm{~g} / \mathrm{L}$ of CNS in artificial freshwater, compared to the control (data not shown). We remind that, despite an absence of genotoxic effects revealed by the nanomaterial (CNS) used in the present in vivo experimental conditions, the inhalation of nano-scaled cellulose may have adverse effects on human health, especially related to pulmonary exposure and because of its potential bio-persistence when inhaled [63]. However, there is a scarcity of chronic, low dose, and repeated exposure studies, making occupational exposure risk assessment of the various life stages of nanocellulose-containing products difficult [63].

\subsubsection{Acute Toxicity Test with Aliivibrio fischeri}

In addition to the chemical and sub-lethal investigations conducted in order to determine the zinc concentrations and assess the safety and efficacy of CNS in preventing zinc induced genotoxicity, a bioassay with Aliivibrio fischeri was conducted. For this purpose, the water used for the co-exposure was tested to check for any qualitative toxicity during $48 \mathrm{~h}$ of incubation. Bacteria like $A$. fischeri is a well-known species that emits bright bioluminescence. The bioluminescence intensity is directly proportional to the metabolic activity of bacteria. Any inhibition of enzymatic activity can cause a decrease in bioluminescence. This property represents a simple way to measure the toxicity of different compounds on this biological system, which constitutes an important component of aquatic microbial community [64]. In Table 4, the results of the ecotoxicity tests with Microtox ${ }^{\circledR}$ system carried out on water samples collected during co-exposure experiments are reported.

Both AFW and CNS only in AFW did not induce any toxic effect on bacteria at both $\mathrm{T}_{0}$ and $48 \mathrm{~h}$. Our test conducted with $\mathrm{Zn}$ (II) at the $50 \mathrm{mg} / \mathrm{L}$ nominal dose showed EC50 values of $85.45 \%$ (67.39-108.4, 95\% Confident Interval C.I.), $8.665 \%$ (6.819-11.01, 95\% C.I.), and $1.937 \%$ (0.8467-4.432, 95\% C.I.), after 5, 15, and $30 \mathrm{~min}$ of incubation, respectively. These results confirm the high sensitivity of Microtox ${ }^{\circledR}$ bioassay to heavy metals $[65,66]$. 
Table 4. EC20 values after 5, 15, and 30 min of incubation and max effects recorded with the Microtox ${ }^{\circledR}$ system. n.d. not detectable data being Max EC20(T48) after 30 min lower than 90\%.

\begin{tabular}{|c|c|c|c|c|c|c|c|c|}
\hline & \multicolumn{4}{|c|}{$\mathbf{T}_{0}$} & \multicolumn{4}{|c|}{$\mathrm{T}_{48}$} \\
\hline & \multicolumn{3}{|c|}{ EC20 (\%) } & \multirow{2}{*}{$\frac{\text { Max Effect (\%) }}{\mathrm{M} \pm \mathrm{SD}}$} & \multicolumn{3}{|c|}{ EC20 (\%) } & \multirow{2}{*}{$\begin{array}{c}\text { Max Effect (\%) } \\
\mathbf{M} \pm \mathbf{S D}\end{array}$} \\
\hline & $5 \mathrm{~min}$ & $15 \mathrm{~min}$ & $30 \mathrm{~min}$ & & $5 \mathrm{~min}$ & $15 \mathrm{~min}$ & $30 \mathrm{~min}$ & \\
\hline AFW & $>90$ & $>90$ & $>90$ & $-10.30 \pm 2.91$ & $>90$ & $>90$ & $>90$ & $-10.46 \pm 12.32$ \\
\hline CNS & $>90$ & $>90$ & $>90$ & $0.75 \pm 0.40$ & $>90$ & $>90$ & $>80$ & n.d. \\
\hline Zn-t CNS & $>90$ & $>90$ & $>90$ & $0.82 \pm 10.12$ & $>90$ & $>90$ & $>90$ & $-16.91 \pm 3.27$ \\
\hline
\end{tabular}

The effect of decontamination induced by CNS in zinc-contaminated water has been verified with bioassay with $A$. fischeri; both samples ( $\mathrm{T}_{0}$ and $48 \mathrm{~h}$ ) collected from the $\mathrm{Zn}$-t CNS treatment had no effect on bacteria bioluminescence, with EC20 values up to $90 \%$ for each exposure time.

Aliivibrio fischeri is considered to play an important ecological role, as it is at the base of most food webs and provides essential ecological and biochemical services, making it a good starting point for any ecotoxicity test [67]. Microtox ${ }^{\circledR}$ is a standard government agency involved in ecotoxicological bioassay in Canada, The Netherlands, France, Germany, Spain, and Sweden. In the United States, it is involved in the Standard Methods for the Examination of Water and Wastewater $[68,69]$ and in Italy, it is one of the bioassays suggested by the Italian Law on classification of dredged marine sediments [70]. Moreover, the Microtox ${ }^{\circledR}$ bioassay has previously been shown to provide a good correlation with other species for a large number of chemical toxicants [71] and EC50 values recorded with this test have been correlated to acute toxicity parameters of vertebrates [69]. Furthermore, it is a simple, fast, robust, and cost-effective assay [68]. According to those characteristics, the bioluminescence test with $A$. fischeri is often chosen as the first test in ecotoxicological evaluations [72] and several studies have involved this test in toxicity evaluation of nanoparticles [67,73-78] and nanostructured materials $[62,79,80]$.

\section{Conclusions}

Our results showed that Zn(II) induced DNA integrity loss and chromosomal mutation in zebra mussel hemocytes. CNS was found, for the first time, to be an effective eco-safe material for Zn genotoxicity prevention in light of their possible use in nanoremediation of freshwater environments. Indeed, in the present study, specimens exposed to $\mathrm{ZnCl}_{2}$ in synthetic freshwater previously flown through polysaccharide-based adsorbent nanosponges did not show any increase in DNA damage respect to the control, thus suggesting the efficacy of polysaccharide-based nanosponges in mitigating $\mathrm{ZnCl}_{2}$ inducedDNA primary damage in zebra mussel haemocytes. A significant decrease in $\mathrm{Zn}$ (II) water concentration was found at $48 \mathrm{~h}$ exposure. Such a concentration decrease was not justified by its bioaccumulation in the organisms. The detection of $\mathrm{Zn}$ (II) in zebra mussels' feces highlighted the importance of bio-deposition in the active process of zinc regulation in D. polymorpha.

The Microtox ${ }^{\circledR}$ assay proved to be a valid and rapid tool for the eco-toxicological evaluation associated with remediation treatments with CNS. Moreover, the contemporary use of the acute toxicity test and sub-lethal endpoints enabled a better understanding of the safety and efficacy of nanomaterials obtained by renewable and sustainable sources.

Author Contributions: Conceptualization, G.F., C.P. and I.C., Supervision, G.F., C.P. and I.C., Resources, G.F., C.P., I.C., D.P. and L.B., Funding acquisition, G.F., C.P. and I.C., Investigation, P.G., M.B., A.F., L.R., G.P., M.P., V.S., M.G., I.B., G.C., L.P. and V.V., Writing-Original Draft, G.F. and P.G., Writing-Review \& Editing, G.F., C.P., I.C., M.B., M.P., P.G., A.F., L.R., L.P., I.B. and V.V., Methodology, G.F., C.P., I.C., P.G. and M.G. This work is part of the degree thesis of M.G. All authors have read and agreed to the published version of the manuscript. 
Funding: This research was funded by Regione Toscana, NanoBonD (Nanomaterials for Remediation of Environmental Matrices associated with Dewatering, Nanomateriali per la Bonifica associata a Dewatering di matrici ambientali) POR CReO FESR Toscana 2014-2020-30/07/2014-LA 1.1.5 CUP 3389.30072014.067000007.

Institutional Review Board Statement: Not applicable for studies involving invertebrates.

Informed Consent Statement: Not applicable.

Data Availability Statement: Data are contained within the article.

Conflicts of Interest: The authors declare no conflict of interest.

\section{References}

1. International Zinc Association. Available online: https://www.zinc.org/environment/ (accessed on 29 June 2021).

2. Jha, A.N.; Cheung, V.V.; Foulkes, M.E.; Hill, S.J.; Depledge, M.H. Detection of genotoxins in the marine environment: Adoption and evaluation of an integrated approach using the embryo-larval stages of the marine mussel Mytilus edulis. Mutat. Res. 2000, 464, 213-228. [CrossRef]

3. Frenzilli, G. Nanotechnology for Environmental and Biomedical Research. Nanomaterials 2020, 10, 2220. [CrossRef]

4. Karn, B.; Kuiken, T.; Otto, M. Nanotechnology and in situ remediation: A review of the benefits and potential risks. Environ. Health Perspect. 2009, 117, 1813-1831. [CrossRef] [PubMed]

5. Otto, M.; Floyd, M.; Bajpai, S. Nanotechnology for site remediation. Remediation 2008, 19, 99-108. [CrossRef]

6. Corsi, I.; Winther-Nielsen, M.; Sethi, R.; Punta, C.; Della Torre, C.; Libralato, G.; Lofrano, G.; Sabatini, L.; Aiello, M.; Fiordi, L.; et al. Ecofriendly nanotechnologies and nanomaterials for environmental applications: Key issue and consensus recommendations for sustainable and ecosafe nanoremediation. Ecotoxicol. Environ. Saf. 2018, 154, 237-244. [CrossRef] [PubMed]

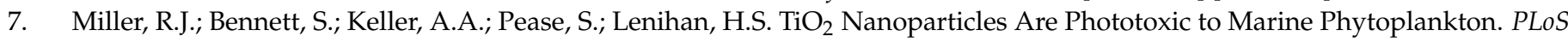
ONE 2012, 7, e30321. [CrossRef]

8. Mathur, A.; Parashar, A.; Chandrasekaran, N.; Mukherjee, A. Nano- $\mathrm{TiO}_{2}$ enhances biofilm formation in a bacterial isolate from activated sludge of a waste water treatment plant. Int. Biodeterior. Biodegrad. 2017, 116, 17-25. [CrossRef]

9. Aruoja, V.; Dubourguier, H.C.; Kasemets, K.; Kahru, A. Toxicity of nanoparticles of CuO, $\mathrm{ZnO}$ and $\mathrm{TiO}_{2}$ to microalgae Pseudokirchneriella subcapitata. Sci. Total Environ. 2009, 407, 1461-1468. [CrossRef]

10. Mortimer, M.; Kasemets, K.; Kahru, A. Toxicity of $\mathrm{ZnO}$ and $\mathrm{CuO}$ nanoparticles to ciliated protozoa Tetrahymena thermophila. Toxicology 2010, 269, 182-189. [CrossRef]

11. Hanna, S.K.; Miller, R.J.; Lenihan, H.S. Deposition of carbon nanotubes by a marine suspension feeder revealed by chemical and isotopic tracers. J. Hazard. Mater. 2014, 279, 32-37. [CrossRef]

12. Callaghan, N.I.; MacCormack, T.J. Ecophysiological perspectives on engineered nanomaterial toxicity in fish and crustaceans. Comp. Biochem. Physiol. Part C Toxicol. Pharmacol. 2017, 193, 30-41. [CrossRef]

13. Oughton, D.; Koin, P.; Bleyl, S.; Filip, J.; Skácelová, P.; Klaas, N.; Von der Kammer, F.; Gondikas, A. Development and Application of Analytical Methods for Monitoring Nanoparticles in Remdation: NanoRem 5 CLAIRE; London, UK, 2017; Volume 6, pp. 32-44. Available online: file:/ / C:/Users/amministratore/Downloads/NanoRem_TB_DL_6-2_monitoring_analytical_toolbox.pdf (accessed on 23 August 2021).

14. Carpenter, A.W.; de Lannoy, C.-F.; Wiesner, M.R. Cellulose nanomaterials in water treatment technologies. Environ. Sci. Technol. 2015, 49, 5277-5287. [CrossRef] [PubMed]

15. Chin, K.-M.; Ting, S.S.; Ong, H.L.; Omar, M. Surface functionalized nanocellulose as a veritable inclusionary material in contemporary bioinspired applications: A review. J. Appl. Polym. Sci. 2018, 135, 46065. [CrossRef]

16. Bossa, N.; Carpenter, A.W.; Kumar, N.; de Lannoy, C.-F.; Wiesner, M. Cellulose nanocrystal zero-valent iron nanocomposites for groundwater remediation. Environ. Sci. Nano 2017, 4, 1294-1303. [CrossRef]

17. Fiorati, A.; Grassi, G.; Graziano, A.; Liberatori, G.; Pastori, N.; Melone, L.; Bonciani, L.; Pontorno, L.; Punta, C.; Corsi, I. Eco-design of nanostructured cellulose sponges for sea-water decontamination from heavy metal ions. J. Clean. Prod. 2020, 246. [CrossRef]

18. Liberatori, G.; Grassi, G.; Guidi, P.; Bernardeschi, M.; Fiorati, A.; Scarcelli, V.; Genovese, M.; Faleri, C.; Protano, G.; Frenzilli, G.; et al. Effect-Based Approach to Assess Nanostructured Cellulose Sponge Removal Efficacyof Zinc Ions from Seawater to Prevent Ecological Riscks. Nanomaterial 2020, 10, 1283. [CrossRef]

19. Guidi, P.; Bernardeschi, M.; Palumbo, M.; Genovese, M.; Scarcelli, V.; Fiorati, A.; Riva, L.; Punta, C.; Corsi, I.; Frenzilli, G. Suitability of a Cellulose-Based Nanomaterial for the Remediation of Heavy Metal Contaminated Freshwaters: A Case-Study Showing the Recovery of Cadmium Induced DNA Integrity Loss, Cell Proliferation Increase, Nuclear Morphology and Chromosomal Alterations on Dreissena polymorpha. Nanomaterials 2020, 10, 1837. [CrossRef]

20. Corsi, I.; Fiorati, A.; Grassi, G.; Bartolozzi, I.; Daddi, T.; Melone, L.; Punta, C. Environmentally Sustainable and Ecosafe Polysaccharide-Based Materials for Water Nano-Treatment: An Eco-Design Study. Materials 2018, 11, 1228. [CrossRef]

21. Riva, L.; Pastori, N.; Panozzo, A.; Antonelli, M.; Punta, C. Nanostructured Cellulose-Based Sorbent Materials for Water Decontamination from Organic Dyes. Nanomaterials 2020, 10, 1570. [CrossRef] 
22. Fiorati, A.; Turco, G.; Travan, A.; Caneva, E.; Pastori, N.; Cametti, M.; Punta, C.; Melone, L. Mechanical and Drug Release Properties of Sponges from Cross-linked Cellulose Nanofibers. ChemPlusChem 2017, 82, 848-858. [CrossRef]

23. Melone, L.; Rossi, B.; Pastori, N.; Panzeri, W.; Mele, A.; Punta, C. TEMPO-Oxidized Cellulose Cross-Linked with Branched Polyethyleneimine: Nanostructured Adsorbent Sponges for Water Remediation. Chempluschem 2015, 80, 1408-1415. [CrossRef] [PubMed]

24. Isogai, A.; Saitoa, T.; Fukuzumia, H. TEMPO-oxidized cellulose nanofibers. Nanoscale 2011, 3, 71-85. [CrossRef]

25. Pierre, G.; Punta, C.; Delattre, C.; Melone, L.; Dubessay, P.; Fiorati, A.; Pastori, N.; Galante, Y.M.; Michaud, P. TEMPO-mediated oxidation of polysaccharides: An ongoing story. Carbohyd. Polym. 2017, 165, 71-85. [CrossRef] [PubMed]

26. Gallo Stampino, P.; Riva, L.; Punta, C.; Elegir, G.; Bussini, D.; Dotelli, G. Comparative Life Cycle Assessment of Cellulose Nanofibres Production Routes from Virgin and Recycled Raw Materials. Molecules 2021, 26, 2558. [CrossRef] [PubMed]

27. Binelli, A.; Cogni, D.; Parolini, M.; Riva, C.; Provini, A. In vivo experiments for the evaluation of genotoxic and cytotoxic effects of Triclosan in Zebra mussel hemocytes. Aquat. Toxicol. 2009, 91, 238-244. [CrossRef]

28. Hietanen, B.; Sunila, I.; Kristoff, R. Toxic effects of zinc on the common mussel Mytilus edulis L. (Bivalvia) in brackish water. I. Physiological and histopathological studies. Ann. Zool. Fenn. 1988, 25, 341-347.

29. Ministry of Foreign Affairs and International Cooperation. Available online: https://www.esteri.it/mae/doc/prontuario_ navigazione_2016/documenti_prontuario/11.normativa\%20sanitaria\%20e\%20presidi\%20medici\%20di\%20bordo/decreto\%20 del\%20presidente\%20della\%20repubblica\%2024\%20maggio\%201988\%20n.\%20236.pdf (accessed on 29 June 2021).

30. Official Gazette of Italian Republic. Available online: https://www.gazzettaufficiale.it/eli/id/1999/10/01/099G0410/sg (accessed on 29 June 2021).

31. Palacio, S.M.; Espinoza-Quiñones, F.R.; Manozzo Galante, R.; Zenatti, D.C.; Seolatto, A.A.; Lorenz, E.K.; Zacarkim, C.E.; Rossi, N.; Rizzutto, M.; Tabacniks, M.H. Correlation between Heavy Metal Ions (Copper, Zinc, Lead) Concentrations and Root Length of Allium cepa L. in Polluted River Water. Braz. Arch. Biol. Technol. 2005, 48, 191-196. [CrossRef]

32. Matos, L.A.; Cunha, A.C.S.; Sousa, A.A.; Maranhão, J.P.R.; Santos, N.R.S.; Gonçalves, M.d.M.C.; Dantas, S.M.M.d.M.; e Sousa, J.M.d.C.; Peron, A.P.; da Silva, F.C.C.; et al. The influence of heavy metals on toxicogenetic damage in a Brazilian tropical river. Chemosphere 2017, 185, 852-859. [CrossRef] [PubMed]

33. Guidi, P.; Bernardeschi, M.; Scarcelli, V.; Cantafora, E.; Beneteddi, M.; Falleni, A.; Frenzilli, G. Lysosomal, genetic and chromosomal damage in haemocytes of the freshwater bivalve (Unio pictorum) exposed to polluted sediments from the River Cecina (Italy). Chem. Ecol. 2017, 33, 516-527. [CrossRef]

34. Spielmann, H.; Balls, M.; Dupuis, J.; Pape, W.J.; Pechovitch, G.; De Silva, O.; Holzhutter, H.G.; Clothier, R.; Desolle, P.; Gerberick, F.; et al. The International EU /COLIPA in vitro phototoxicity validation study: Results of phase II (Blind Trial). Part 1: The 3T3 NRU phototoxicity test. Toxicol. In Vitro 1998, 12, 305-327. [CrossRef]

35. Guidi, P.; Frenzilli, G.; Benedetti, M.; Bernardeschi, M.; Falleni, A.; Fattorini, D.; Regoli, F.; Scarcelli, V.; Nigro, M. Antioxidant, genotoxic and lysosomal biomarkers in the freshwater bivalve (Unio pictorum) transplanted in a metal polluted river basin. Aquat. Toxicol. 2010, 100, 75-83. [CrossRef] [PubMed]

36. Kumaravel, T.S.; Jha, A.N. Reliable Comet assay measurements for detecting DNA damage induced by ionising radiation and chemicals. Mutat. Res. Genet. Toxicol. Environ. Mutagen. 2006, 605, 7-16. [CrossRef] [PubMed]

37. Fenech, M. Cytokinesis-block micronucleus cytome assay. Nat. Protoc. 2007, 2, 1084-1104. [CrossRef] [PubMed]

38. ISO 11348-1:2007 Water Quality. Available online: https://www.iso.org/obp/ui/\#iso:std:iso:11348:-2:ed-2:v1:en (accessed on 29 June 2021).

39. Isprambiente.gov.it. Available online: https://www.isprambiente.gov.it/contentfiles/00006700/6770-manuale-apat-icram-20 07.pdf (accessed on 29 June 2021).

40. Lovell, D.P.; Omori, T. Statistical issues in the use of the comet assay. Mutagenesis 2008, 23, 171-182. [CrossRef] [PubMed]

41. Tice, R.R.; Agurell, E.; Anderson, D.; Burlinson, B.; Hartmann, A.; Kobayashi, H.; Miyamae, Y.; Rojas, E.; Ryu, J.C.; Sasaki, Y.F. Single cell gel/comet assay: Guidelines for in vitro and in vivo genetic toxicology testing. Environ. Mol. Mutagen. 2000, 35, 206-221. [CrossRef]

42. Nacci, D.E.; Cayula, S.; Jackim, E. Detection of DNA damage in individual cells from marine organisms using the single cell gel assay. Aquat. Toxicol. 1996, 35, 197-210. [CrossRef]

43. Buschini, A.; Carboni, P.; Martino, A.; Poli, P.; Ross, C. Effects of temperature on baseline and genotoxicant-induced DNA damage in haemocytes of Dreissena polymorpha. Mutat. Res. 2003, 537, 81-92. [CrossRef]

44. Mersch, J.; Beauvais, M.-N.; Nagel, P. Induction of micronuclei in haemocytes and gill cells of zebra mussels, Dreissena polymorpha, exposed to clastogens. Mutat. Res. Genet. Toxicol. 1996, 371, 47-55. [CrossRef]

45. Pavlica, M.; Klobučar, G.I.V.; Mojaš, N.; Erben, R.; Papeš, D. Detection of DNA damage in haemocytes of zebra mussel using comet assay. Mutat. Res. Genet. Toxicol. Environ. Mutagen. 2001, 490, 209-214. [CrossRef]

46. Banu, B.S.; Danadevi, K.; Rahman, M.F.; Ahuja, Y.R.; Kaiser, J. Genotoxic effect of monocrotophos to sentinel species using the Comet assay. Food Chem. Toxicol. 2001, 39, 361-366. [CrossRef]

47. Farombi, E.O.; Adelowo, O.A.; Ajimoko, Y.R. Biomarkers of oxidative stress and heavy metal levels as indicators of environmental pollution in African catfish (Clarias gariepinus) from Nigeria Ogun River. Int. J. Environ. Res. Public Health 2007, 4, 158-165. [CrossRef] [PubMed] 
48. Scalon, M.C.S.; Rechenmacher, C.; Siebel, A.M.; Kayser, M.L.; Rodrigues, M.T.; Maluf, S.W.; Rodrigues, M.A.S.; Silva, L.B. Evaluation of Sinos River water genotoxicity using the comet assay in fish. Braz. J. Biol. 2010, 70, 1217-1222. [CrossRef] [PubMed]

49. Zhang, Y.F.; Chen, S.Y.; Qu, A.O.; Adeleye, A.O.; Di, Y.N. Utilization of isolated marine mussel cells as an in vitro model to assess xenobiotics induced genotoxicity. Toxicol. In Vitro 2017, 44, 219-229. [CrossRef] [PubMed]

50. Pearson, H.B.; Dallas, L.J.; Comber, S.D.W.; Braungardt, C.B.; Worsfold, P.J.; Jha, A.N. Mixtures of tritiated water, zinc and dissolved organic carbon: Assessing interactive bioaccumulation and genotoxic effects in marine mussels, Mytilus galloprovincialis. J. Environ. Radioact. 2018, 187, 133-143. [CrossRef] [PubMed]

51. Bagdonas, E.; Vosylienė, M.Z. A study of toxicity and genotoxicity of copper, zinc and their mixture to rainbow trout (Oncorhynchus mykiss). Biologija 2006, 1, 8-13.

52. Majone, F.; Beltrame, C.; Brunetti, R. Frequencies of micronuclei detected on Mytilus galloprovincialis by different staining techniques after treatment with zinc chloride. Mutat. Res. 1988, 209, 131-134. [CrossRef]

53. Fernández, B.; Campillo, J.A.; Martínez-Gómez, C.; Benedicto, J. Micronuclei and other nuclear abnormalities in mussels (Mytilus galloprovincialis) as biomarkers of cyto-genotoxic pollution in mediterranean waters. Environ. Mol. Mutagen. 2011, 52, 479-491. [CrossRef] [PubMed]

54. Varotto, L.; Domeneghetti, S.; Rosani, U.; Manfrin, C.; Cajaraville, M.P.; Raccanelli, S.; Pallavicini, A.; Venier, P. DNA Damage and Transcriptional Changes in the Gills of Mytilus galloprovincialis Exposed to Nanomolar Doses of Combined Metal Salts $(\mathrm{Cd}, \mathrm{Cu}$, Hg). PLoS ONE 2013, 8, e54602. [CrossRef] [PubMed]

55. Binelli, A.; Pedriali, A.; Riva, C.; Parolini, M. Illicit drugs as new environmental pollutants: Cyto-genotoxic effects of cocaine on the biological model Dreissena polymorpha. Chemosphere 2012, 86, 906-911. [CrossRef]

56. Kononenko, V.; Repar, N.; Marušič, N.; Drašler, B.; Romih, T.; Hočevar, S.; Drobne, D. Comparative in vitro genotoxicity study of $\mathrm{ZnO}$ nanoparticles, $\mathrm{ZnO}$ macroparticles and $\mathrm{ZnCl}_{2}$ to $\mathrm{MDCK}$ kidney cells: Size matters. Toxicol. In Vitro 2017, 40, 256-263. [CrossRef]

57. Paladini, G.; Venuti, V.; Almásy, L.; Melone, L.; Crupi, V.; Majolino, D.; Pastori, N.; Fiorati, A.; Punta, C. Cross-linked cellulose nano-sponges: A small angle neutron scattering (SANS) study. Cellulose 2019, 26, 9005-9019. [CrossRef]

58. Paladini, G.; Venuti, V.; Crupi, V.; Majolino, D.; Fiorati, A.; Punta, C. FTIR-ATR analysis of the H-bond network of water in branched polyethyleneimine/TEMPO-oxidized cellulose nano-fiber xerogels. Cellulose 2020, 27, 8605-8618. [CrossRef]

59. Kraak, M.H.; Lavy, D.; Schoon, H.; Toussaint, M.; Peeters, W.H.; van Straalen, N.M. Ecotoxicity of mixtures of metals to the zebra mussel Dreissena polymorpha. Environ. Toxicol. Chem. 1994, 13, 109-114. [CrossRef]

60. Klerks, P.L.; Fraleigh, P.C. Uptake of nickel and zinc by the zebra mussel Dreissena polymorpha. Arch. Environ. Contam. Toxicol. 1997, 32, 191-197. [CrossRef] [PubMed]

61. Rainbow, P.S.; White, S.L. Comparative strategies of heavy metal accumulation by crustaceans: Zinc, copper and cadmium in a decapod, an amphipod and a barnacle. Hydrobiologia 1989, 174, 245-262. [CrossRef]

62. Sargsyan, A.; Simonyan, A.; Hovhannisyan, G.; Arakelyan, M.; Aroutiounian, R. Application of the comet assay, micronucleus test and global DNA methylation analysis in Darevskia lizards as a sentinel organism for genotoxic monitoring of soil pollution. Mutat. Res./Genet. Toxicol Environ. Mutagen. 2019, 842, 117-124. [CrossRef]

63. Stoudmann, N.; Schmutz, M.; Hirsch, C.; Nowack, B.; Som, C. Human hazard potential of nanocellulose: Quantitative insights from the literature. Nanotoxicology 2020, 14, 1241-1257. [CrossRef]

64. Zheng, H.; Liu, L.; Lu, Y.; Long, Y.; Wang, L.; Ho, K.-P.; Wong, K.-Y. Rapid determination of nanotoxicity using luminous bacteria. Anal. Sci. 2010, 26, 125-128. [CrossRef]

65. Kaiser, K.L.E.; Devillers, J. (Eds.) Ecotoxicology of Chemicals to Photobacterium phosphoreum; Gordon \& Breach Science: Langhorne, PA, USA, 1994.

66. Kong, J.C.; Bitton, G.; Koopman, B.; Jung, K.H. Heavy metal toxicity testing in environmental samples. Rev. Environ. Contam. Toxicol. 1995, 142, 119-147. [CrossRef]

67. Casado, M.P.; Macken, A.; Byrne, H.J. Ecotoxicological assessment of silica and polystyrene nanoparticles assessed by multitrophic test battery. Environ. Int. 2013, 51, 97-105. [CrossRef]

68. Parvez, S.; Venkataraman, C.; Mukherji, S. A review on advantages of implementing luminescence inhibition test (Vibrio fischeri) for acute toxicity prediction of chemicals. Environ. Int. 2006, 32, 265-268. [CrossRef]

69. Park, K.; Hee, S.Q. Effect of dust on the viability of Vibrio fischeri in the Microtox test. Ecotoxicol. Environ. Saf. 2001, 50, 189-195. [CrossRef] [PubMed]

70. Official Gazette of Italian Republic. Available online: https://www.gazzettaufficiale.it/eli/id/2016/09/06/16G00184/sg (accessed on 29 June 2021).

71. Kaiser, K.L.E. Correlations of Vibrio fischeri bacteria test data with bioassay data for other organisms. Environ. Health Perspect. 1998, 106, 583-591. [PubMed]

72. Bonnet, M.; Massard, C.; Veisseire, P.; Camares, O.; Awitor, K.O. Environmental toxicity and antimicrobial efficiency of titanium dioxide nanoparticles in suspension. J. Biomater. Nanobiotechnol. 2015, 6, 213-224. [CrossRef]

73. Mortimer, M.; Kasemets, K.; Heinlaan, M.; Kurvet, I.; Kahru, A. High throughput kinetic Vibrio fischeri bioluminescence inhibition assay for study of toxic effects of nanoparticles. Toxicol. In Vitro 2008, 22, 1412-1417. [CrossRef]

74. Velzeboer, I.; Hendriks, A.J.; Ragas, A.M.J.; Van de Meent, D. Aquatic ecotoxicity tests of some nanomaterials. Environ. Toxicol. Chem. 2008, 27, 1942-1947. [CrossRef] 
75. Lopes, I.; Ribeiro, R.; Antunes, F.E.; Rocha-Santos, T.A.P.; Rasteiro, M.G.; Soares, A.M.V.M.; Gonçalves, F.; Pereira, R. Toxicity and genotoxicity of organic and inorganic nanoparticles to the bacteria Vibrio fischeri and Salmonella typhimurium. Ecotoxicology 2012, 21, 637-648. [CrossRef]

76. Minetto, D.; Libralato, G.; Volpi Ghirardini, A. Ecotoxicity of engineered $\mathrm{TiO}_{2}$ nanoparticles to saltwater organisms: An overview. Environ. Int. 2014, 66, 18-27. [CrossRef]

77. Baniamerian, H.; Tsapekos, P.; Alvarado-Morales, M.; Shokrollahzadeh, S.; Safavi, M.; Angelidaki, I. Effect of surfactants on photocatalytic toxicity of $\mathrm{TiO}_{2}$-based nanoparticles toward Vibrio fischeri marine bacteria. Inorg. Chem. Commun. 2020, 116, 107936. [CrossRef]

78. Zeng, C.; Nguyen, C.; Boitano, S.; Field, J.A.; Shadman, F.; Sierra-Alvarez, R. Toxicity of abrasive nanoparticles $\left(\mathrm{SiO}_{2}, \mathrm{CeO}_{2}\right.$, and $\mathrm{Al}_{2} \mathrm{O}_{3}$ ) on Aliivibrio fischeri and human bronchial epithelial cells (16HBE14o). J. Nanopart. Res. 2021, 23, 49. [CrossRef]

79. Bilal, M.; Rasheed, T.; Mehmood, S.; Tang, H.; Ferreira, L.F.R.; Bharagava, R.N.; Iqbal, H.M.N. Mitigation of environmentallyrelated hazardous pollutants from water matrices using nanostructured materials-A review. Chemosphere 2020, 253, 126770. [CrossRef] [PubMed]

80. Coelho, F.P.; Rabelo, T.S.; da Cruz Felix, L.; Bila, D.M.; Ritter, E. Characterization and ecotoxicological evaluation of nanostructured chitosan particles. In Sustainable Environmental Geotechnics; Lecture Notes in Civil Engineering, Reddy, K.R., Agnihotri, A.K., Yukselen-Aksoy, Y., Dubey, B.K., Bansal, A., Eds.; Springer: Cham, Switzerland, 2020; Volume 89. [CrossRef] 